\title{
AN INVESTIGATION ON PERCEIVED ANXIETY AND SPEAKING SKILLS: THE CASE OF INDONESIAN EFL STUDENT TEACHERS
}

\author{
Ridwan Jihan Nabilah \\ Teacher Training and Education Faculty of Borneo \\ Tarakan UniversityTarakan, North Kalimantan Province, Indonesia
}

\begin{abstract}
The aims of this study were to explore any possible existence of linkage between perceived anxiety and speaking skills, and to determine any significant difference in speaking skills between the students who got higher level of speaking anxiety and those who were in lower level of speaking anxiety. This research employed a quantitative method. Sixty-nine second semester student teachers of the English Education Department of Borneo Tarakan University were taken as the sample of this research. Data were collected using questionnaire, speaking test, and interview. Foreign Language Classroom Anxiety Scale (FLCAS) questionnaire developed by Horwitz et al. (1986) was used to rate students' perceived anxiety and speaking test was carried out to assess students' speaking skills. The Pearson product moment correlation and the independent sample t-test were employed in analyzing the acquired data. The result of this study showed that, first, there was no relationship between speaking anxiety and speaking skills because the r-test value $(0.221)$ was lower than the r-table $(0.235)$ and the sig. value for 2-tailed (0.068) was higher than the level of significance $(0.05)$ which indicated there was no relationship. Second, the students who were in higher level of anxiety got better speaking skills (mean score: 65.6) than those who were in lower level of anxiety (59.7). The result of Independent sample t-test proved that the sig. value for 2-tailed (0.152) was higher than the level of significance $(0.05)$. The result of the interview confirmed that internal and external factors affected the students' speaking skills. Those factors were psychological state (lack of confidence, discourage, anxiety itself), linguistic knowledge (limited vocabulary, poor grammar, mispronunciation), general knowledge (topics being discussed), performance situations (time, preparation, amount of support), and the learning atmosphere (classroom climate).
\end{abstract}

Keywords: perceived anxiety, speaking skills, student teachers

\section{Introduction}

English has four primary skills to master. There are listening, speaking, reading, and writing. Among those four skills, one of the essential skill is speaking. According to Richard (2008), mastering speaking skills is the primary concern for foreign language learners and as a benchmark in measuring their language learning success. It means that speaking as one of the supporting success in learning a language. As language is a communication tool, speaking skill plays an essential part in learning a language. It is also a skill that often used in everyday life to bond with others. In Indonesia, English is a foreign language taught at lower to higher education. As a foreign language, it is rarely used to communicate with each other. The chance of students speaking English is only in the English class. It makes them unaccustomed to speak English well. Education First (2020) reported that Indonesia was on the $74^{\text {th }}$ out of 100 nations in Asia, included in the low category with a score of 50.06. It shows that Indonesia is still a lack of English. Frankly, many EFL students express inability of English, even commit the failure in speaking (Tanveer, 2007). Besides, Horwitz (2001) says that thirty percent of all foreign language learners encounter some language anxiety levels. Spefically, Horwitz et al. (1986), found that the students were more anxiety in speaking skill than the other language skills. This is inline with the result of preliminary research conducted to the second semester student teachers of the English Education Department of Borneo Tarakan University which uncoveredthat $10 \%$ of them were sometimes still anxious about speaking up in English. Especially when they were requested to practice speaking in front of the class accidentally, some of them also felt less confident in their abilities. They thought that the other students were more fluent thanthey did. In addition, they were afraid of being evaluated in speaking. They felt anxious if theirperformance did not fulfil the expectation of lecturer. They also got sweating and heart- pounding when they felt anxious. Those problems could certainly obstruct many things in theirlearning process as well as their learning achievement. 
One of the obstacles that can influence students' achievement is anxiety. Horwitz et al. (1986) define "Anxiety is the subjective feeling of tension, apprehension, nervousness, and worry associated with an arousal of the autonomic nervous system." Anxiety is obviously a problem in English learning and has an adverse effect on the spoken English of several students. It could make the learning outcome to be not optimal. Woodrow (2006) states that the anxiety encountered when learning English can be devastating and may affect students' ability to adapt to the target language interaction and eventually affect their ability to achieve learning goals. Horwitz et al. (1986), for instance, say that very anxious students veer to avoid participating in classroom interactions, they seem completely to be unprepared or uninterested, lack of skills, lack of background knowledge, or low motivation. Once the anxiety arises, they may suffer to articulate their opinions.

Furthermore, Chen (2011) states that anxiety can be the most influential emotional barrier to language learning. This is due to anxiety is a combination of displeasing emotional responses and psychological distress. Anxiety can therefore bring motive strength or difficulty. In one side, a certain amount of anxiety will give students the courage to participate in learning process. In other side, an extreme level of anxiety can cause students to avoid learning programs. Therefore, it is very important for teachers to be responsive to this issue in the process of teaching and afford assistance to decrease the students' anxiety.

By having the facts above, this research endeavored to investigate the linkage between perceived anxiety and speaking skills and therefore these two research questions were addressed:

a. Is there any significant link or relationship between perceived anxiety and speaking skills of the second semester EFL student teachers of English Education Department of Borneo Tarakan University in 2019/2020 academic year?

b. Do students with higher and lower levels of perceived anxiety differ in their speaking skills?

\section{Research Method \\ Design}

Considering to the objective of this research which was to explore the linkage between perceived anxiety and speaking skills, this research used correlation design as one of kind in quantitative approach. Correlation research provides a prospect for the investigator to predict scores and define the link among variables (Creswell, 2012) and (Gay et al., 2012). This research is intended to discover and determine the degree of association between two variables covering an independent variable (perceived anxiety) and dependent variable (speaking skills) in the second semester student teachers of English Education Department of Borneo Tarakan University. By having that, the researcher did not give any treatment to the students but collect the data of perceived anxiety and speaking skills.

\section{Participants}

The participants of this research was all of the second semester student teachers of the English Education Department of Borneo Tarakan University which consisted of 69 students from class A and B.

Table 3.1 The number of research sample

\begin{tabular}{ccc}
\hline No & Class & Number of Students \\
\hline 1 & A & 42 Students \\
2 & B & 27 Students \\
\hline & Total & 69 Students \\
\hline
\end{tabular}

\section{Instruments}

The main instruments used to gather the data were a questionnaire and a speaking test. The questionnaire was adopted from Foreign Language Classroom Anxiety Scale (FLCAS) developed by Horwitz et al. (1986). The FLCAS consisted of 33 items which covered 11 items of communication apprehension, 14 items of speaking anxiety, and 7 items of negative 


\section{ULUSLARARASI SOSYAL BILIMLER VE INOVASYON KONGRESI}

24-25 Mayıs 2021, ANKARA

evaluation fear. All items in this scale revealed internal reliability and attained the alpha $(\alpha)$ coefficient of 0.93 which created a significant correlation between the item and the total scale. It means that this questionnaire was credible to use. To strengthen the data, a semi-structured interview was carried out to four representative students in order to gain more information on their anxiety.

\section{Data Gathering Procedures}

After obtaining the lecturer' permission for accomplishing the research, the FLCAS questionnaire was firstly distributed using google form. The next session, speaking test was conducted by online. Afterwards, the typical students were probed for an interview. There were four students who were randomly taken as the representative of anxious level, mildly anxious level, relaxed level, and very relaxed level. The interview was completed within a week after the speaking test was conducted. The speaking and interview processes were recorded and transliterated, respectively, for analysis (Flick, 2007).

\section{Data Analysis}

The quantitative stage of this research was firstly administered 33 items on the five-point Likert scale of FLCAS in which the points were added by assigning a score of 1 for the "Strongly Disagree" response which perceived as very low anxiety, and a score of 5 for "Strongly Agree" response which perceived as very high anxiety. For items: 2, 5, 8, 11, 14, 18, 22,28 , and 32 the scores were reversed. Then, the students' speaking skills were scored using scoring rubrics from (Brown, 2004).

The participants' overall scores from the result of FLCAS questionnaire and speaking test were previously conducted to test the statistical assumptions using normality and homogeneity tests. The results of both assumption tests required for testing the hypotheses suggested that the data were corresponded to the use of parametric procedures.

The Pearson correlation analysis was then employed to determine whether there was any relationship between students' perceived anxiety and speaking skills. The independent samples t-test was also carried out to determine the difference in speaking skills between the students who were perceived into higher level of anxiety and those who were perceived into lower level of anxiety. These statistical procedures were run with the help of the SPSS statistical program.

The qualitative stage was the analysis of the interview result using content analysis to seek the common patterns of the responses.

\section{Findings and Discussion \\ Findings \\ Descriptive Statistics Analysis}

Perceived anxiety and speaking skills were two variables which were examined in this research. The independent variable (X) was perceived anxiety and the dependent variable (Y) was speaking skills. The data were obtanined by using FLCAS and speaking test. The results of descriptive statistics for each variable were presented from the minimum and maximum score, mean score, and standard deviation. In short, the descriptive statistics of both variables are portrayed in the Table 4.1 below:

Table 4.1 The descriptive statistics of the research variables

\begin{tabular}{cccc}
\hline Descriptive Statistics & N & Anxiety & Speaking skills \\
\hline Minimum Score & 69 & 50 & 44 \\
Maximum Score & 69 & 120 & 96 \\
Mean & 69 & 88.19 & 63.94 \\
Standard Deviation & 69 & 13.016 & 12.806 \\
\hline
\end{tabular}

The obtained information from the Table above, the mean score of students' anxiety and speaking skills were 88.19 and 63.93 respectively with relatively the same result of standard deviation. Those score can be interpreted that the students' perceived anxiety was in mildly anxious level and their speaking skills was in fair category. 


\section{Students' perceived anxiety}

The questionnaire results were classified into five levels of anxiety, namely: very anxious, anxious, mildly anxious, relaxed, and very relaxed (Sinaga et al., 2020). The distribution of anxiety levels is presented in Table 4.2:

Table 4.2 The classification of students' perceived anxiety

\begin{tabular}{|c|c|c|c|}
\hline Category & Interval & Frequency & Percentage \\
\hline Very Anxious & $124-165$ & 0 & $0 \%$ \\
\hline Anxious & $108-123$ & 4 & $5.8 \%$ \\
\hline Mildly Anxious & $87-107$ & 32 & $46.4 \%$ \\
\hline Relaxed & $66-86$ & 32 & $46.4 \%$ \\
\hline Very Relaxed & $33-65$ & 1 & $1.4 \%$ \\
\hline \multicolumn{2}{|c|}{ Total } & 69 & $100 \%$ \\
\hline
\end{tabular}

The result showed that the majority of students (each 32 or $46.4 \%$ ) perceived mildly anxious and relaxed in their speaking class. The rest of the students, that is, 4 or $5.8 \%$ students felt anxious and only 1 or $1.4 \%$ student felt very relaxed.

\section{Students' speaking skills}

The distribution of students' speaking scores is presented in Table 4.3:

Table 4.3 The classification of students' speaking skills

\begin{tabular}{|c|c|c|c|c|c|}
\hline Classification & Alphabet & Interval Score & Number & Frequency & Percentage \\
\hline Very Good & $\bar{A}$ & $\geq 80$ & 4.0 & 10 & $14.5 \%$ \\
\hline Good to Very Good & $\mathrm{AB}$ & $75-80$ & 3.5 & 5 & $7.2 \%$ \\
\hline Good & B & $70-75$ & 3.0 & 4 & $5.8 \%$ \\
\hline Fair to Good & $\mathrm{BC}$ & $65-70$ & 2.5 & 8 & $11.6 \%$ \\
\hline Fair & $\mathrm{C}$ & $60-65$ & 2.0 & 17 & $24.6 \%$ \\
\hline Poor to Fair & $\mathrm{CD}$ & $55-60$ & 1.5 & 8 & $13.0 \%$ \\
\hline Poor & $\mathrm{D}$ & $40-55$ & 1.0 & 16 & $23.2 \%$ \\
\hline Very Poor & $\mathrm{E}$ & $<40$ & 0.0 & 0 & $0 \%$ \\
\hline \multicolumn{4}{|c|}{ Total } & 69 & $100 \%$ \\
\hline
\end{tabular}

The speaking skills were divided into eight classification, namely: very good, good to very good, good, fair to good, fair, poor to fair, poor, and very poor (Score Classification of Borneo Tarakan University). Table 4.3 showed that the students' speaking skills were spread into all classifications, except very poor category.

\section{Inferential Statistics Analysis}

\section{The relationship between perceived anxiety and speaking skills}

The first hypothesis was about the relationship between perceived anxiety and speaking skills. The result of Pearson product moment is in Table 4.6 below:

Table 4.6 The correlation result between perceived anxiety and speaking skills

\begin{tabular}{llcc}
\hline & & Anxiety & Speaking skills \\
\hline Anxiety & Pearson Correlation & 1 & .221 \\
& Sig. (2-tailed) & & .068 \\
& N & 69 & 69 \\
Speaking skills & Pearson Correlation & .221 & 1 \\
& Sig. (2-tailed) & .068 & \\
& $\mathrm{~N}$ & 69 & 69 \\
\hline
\end{tabular}

Based on the result of Pearson product-moment above, the coefficient or the $r_{\text {test }}(0.221)$ was lower than $r_{\text {table }}(0.235)$. The value of probability $(p)$ or significance (sig.2-tailed) was 


\section{ULUSLARARASI SOSYAL BILIMLER VE INOVASYON KONGRESI}

24-25 Mayıs 2021, ANKARA

0.068. It means that $p=0.068$ was smaller than $\alpha=0.05$. The result indicates there was no relationship between students' perceived anxiety and their speaking skills. Thus, there was adequate evidence to suggest that $\mathrm{H}_{0}$ was accepted and $\mathrm{H}_{\mathrm{a}}$ was rejected. The $r_{\text {test }}(0.221)$ drew in positive (+) result of correlation index which means that the higher the anxiety the students felt, the higher the speaking skills they achieved. This condition was actually not expected to be happened. In fact, this result indicates that there was no significant relationship between perceived anxiety and speaking skills. In other words, the students who were in relaxed condition (low anxiety) did not guarantee that they got higher speaking skills.

\section{The differences of students' speaking skills}

The second hypothesis was about the significant difference in speaking skills between the students who had higher level of anxiety and who had lower level of anxiety. To do so, each $27 \%$ of students was arranged to indicate the extreme level of anxiety in order to have the students with higher level of anxiety and lower level of anxiety. An independent sample t-test was used to find out the difference of students' speaking skills seen from both ends of anxiety levels as illustrated in Table 4.7 below:

Table 4.7 The descriptive statistics of speaking score based on the level of anxiety

\begin{tabular}{clccc}
\hline \multicolumn{1}{c}{ Group } & N & Mean & Std. Deviation \\
\hline $\begin{array}{c}\text { Speaking } \\
\text { skills }\end{array}$ & $\begin{array}{l}\text { Higher level of } \\
\text { anxiety }\end{array}$ & 19 & 65.68 & 14.442 \\
\cline { 2 - 2 } & $\begin{array}{l}\text { Lower level of } \\
\text { anxiety }\end{array}$ & 19 & 59.79 & 10.020
\end{tabular}

Based on the table above it can be seen that the mean of students' speaking score who were in higher level of anxiety was 65 and the standard deviation was 14.442. And the mean of students' speaking score who were in lower level of anxiety was 59.79 and the standard deviation was 10.020 . It can be said that the students who were in higher level of anxiety got better speaking skills that those in lower level of anxiety. In other words, the very nervous students had higher performance in speaking than those who were in relax state or condition. Furthermore, the t-test result can be seen in Table 4.8 below:

Table 4.8 The independent sample t-test

\begin{tabular}{|c|c|c|c|c|c|c|c|c|c|}
\hline & \multicolumn{3}{|c|}{$\begin{array}{c}\text { Levene's Test for } \\
\text { Equality of Variances }\end{array}$} & \multicolumn{4}{|c|}{ t-test for Equality of Means } & & \\
\hline & \multirow[t]{2}{*}{$\mathrm{F}$} & \multirow[t]{2}{*}{ Sig. } & \multirow[t]{2}{*}{$\mathrm{t}$} & \multirow[t]{2}{*}{ df } & \multirow[t]{2}{*}{$\begin{array}{l}\text { Sig. (2- } \\
\text { tailed) }\end{array}$} & \multirow[t]{2}{*}{$\begin{array}{c}\text { Mean } \\
\text { Difference }\end{array}$} & \multirow[t]{2}{*}{$\begin{array}{l}\text { Std. Error } \\
\text { Difference }\end{array}$} & \multicolumn{2}{|c|}{$\begin{array}{l}95 \% \text { Confidence } \\
\text { Interval of the } \\
\text { Difference }\end{array}$} \\
\hline & & & & & & & & Lower & Upper \\
\hline $\begin{array}{l}\text { Equal variances } \\
\text { assumed }\end{array}$ & 1.621 & .211 & 1.462 & 36 & .152 & 5.895 & 4.032 & -2.284 & 14.073 \\
\hline $\begin{array}{l}\text { Equal variances } \\
\text { not assumed }\end{array}$ & & & 1.462 & 32.069 & .154 & 5.895 & 4.032 & -3.218 & 14.108 \\
\hline
\end{tabular}

The result of independent sample t-test showed that the sig. Levene's Test for equality of variance $(0.211)$ was higher than 0.05 which meant that the data variance was homogen. Furthermore, the result of Sig. 2-tailed (0.152) was higher than the level of significance $(0.05)$ which indicated that $\mathrm{H}_{0}$ was accepted by rejecting $\mathrm{H}_{\mathrm{a}}$. It means that there was no significant difference in speaking skills between the students who had higher level of anxiety and those who had lower level of anxiety. Again, however, the mean score of students in higher level of anxiety (nervous) was greater 5.89 points that that of those who were in lower level of anxiety (relaxed).

\section{Discussion}

Concerning to the result of correlation test, it was confirmed that there was no any linkage between perceived anxiety and speaking skills of the second semester student teachers of English Education Department of Borneo Tarakan University $(r=0.221)$. And the result of independent sample t-test revealed that the $p$ value of sig. 2-tailed $(0.152)$ was higher than the 
level of significance (0.05) which verified that the students who were in higher level of anxiety had no difference in speaking skills than those who were in lower level of anxiety.

The result of this research is then in agreement with the previous related researches who agreed that anxiety has no positive relationship with English proficiency in general and speaking skills in specific. They are Chen (2008), Bashosh et al. (2013), Doğan \& Akbarov (2014), Mauludiyah (2014), and Rustini (2017).

The insignificant result of relationship between anxiety and speaking skills probably occured since anxiety was not the solitary aspect which influenced the students' oral skill. The students stated that their speaking score was not only influenced by the anxiety itself but also other factors. Those factors were the reason why anxiety and speaking skill were not correlated in this research. It was found that there were several factors that affect students' language performance beside anxiety. These factors refer to internal and external factors, including psychological state (lack of confidence, discourage, anxiety itself), linguistic knowledge (limited vocabulary, poor grammar, mispronunciation), general knowledge (topics being discussed), performance situations (time, preparation, amount of support), and the learning atmosphere (classroom climate).

The results of interview showed that the students experienced speaking anxiety. Students reported:

Yes, sometimes I do feel anxious. Example like if am demanded to speak in front of the class or a lot of people. (Student 1)

Yes I often feel anxious, especially when I lack of vocabulary or when I speak with wrong grammar and mispronounced a word. (Student 2)

Yes I often feel anxious because I'm not confident with myself. (Student 3)

Yes I often feel anxious in speaking. (Student 4)

Beside the speaking anxiety itself, the students felt not confident and discouraged in speaking class as reported by following students:

I think it could be and self confidence too. (Student 3 )

Yes, I think it can affect speaking score. If I don't know the topic assigned for us to discuss, I cannot enjoy the class activity. (Student 4)

... I mean I used to postpone to complete my tasks. (Student 2)

Confidence was perceived as a factor that influences students' performance. If the learners were not confident in their speaking performance, even if they had mastered the language, they would feel some anxiety and then they would fail in speaking class (Tuan \& Mai, 2015).

Students' linguistic competence was another factor affecting their speaking skills. The students felt more anxious, if they did not have sufficient range of vocabulary mastery, grammatical knowledge, good command of pronunciation, etc. as responded by Student 1 and 2:

I think the factor that affect my score in speaking are lack of vocabulary and wrong grammar. Anxiety is like companion factor. (Student 1)

... especially when I lack of vocabulary or when I speak with wrong grammar and mispronounced a word. (Student 2)

Bashir et al. (2016) affirm that the students should apprehend that speaking is related to utilizing the appropriate vocabularies in the correct sequence with the precise pronunciation. Those who have difficulties in this area prefer to remain silent in their English interaction.

The students also thought that topical knowledge became an issue that could made them get stuck in speaking. Student 3 and 4 replied:

Talking about things that affect my speaking is that I sometimes don't have enough knowledge of the topics we are discussing. (Student 3)

... If I don't know the topic assigned for us to discuss .... (Student 4)

Performance condition such as time, preparation, amount of support was another problem that that students should have the effort in order they can cope with speaking hindrance. Student 1 and 4 attested:

I think it's preparation can also affect my speaking score. The time I spent to prepare my presentation is limited .... (Student 2)

I think supporting from friends. We should give support to each other, no mocking or 
bullying, no staring, etcetera. (Student 4)

Ganschow \& Sparks (1996) believe that difficulty in authentic presentation and various language learning preparations is one of the contributing factors for some students.

The classroom atmosphere was needed to create in order to provide a comfort situation so that the students could learn with fun. Student 1 and 4 responded:

Sometimes my anxiety decrease when the class atmosphere is not threatening, like the audience or my friends facial expression also affect me to feel anxious or not. (Student 1)

... no mocking or bullying, no staring, etcetera. (Student 4)

A study shows that classroom environment, rather than distinctive classroom interaction, can reduce students' level of anxiety. The effects of classroom circumtance on students' anxiety were related to high and low levels of anxiety (Palacios in Horwitz, 2001). It can be said that students had their own speaking anxiety when they learned English and affected their performance differently according to the situation.

\section{Conclusion}

Based on the result in the aforementioned session, it was concluded that most of the second semester student teachers of English Education Department of Borneo Tarakan University in academic year 2019/2020 experienced mildly anxiety and fair speaking skills. The result of FLCAS questionnaire and speaking test showed that the mean scores were 88.19 and 63.94 respectively. The correlation analysis was found the $r$-test $=0.221$ which indicated that both variables were not correlated. There was also no significant difference in speaking skills between the students who had higher level of anxiety and those who had lower level of anxiety. The result of independent sample t-test revealed $p=0.152$ which was higher than $\alpha=0.05$.

Overall, there is no tendency that the students who were in relaxed condition (low anxiety) did not guarantee that they got higher speaking skills. Even, the students who were very anxious (higher level of anxiety) got better speaking skills than those who were very relaxed (lower level of anxiety). Hence, the inconsequential result occured because anxiety was not the single aspect that influenced speaking skills of the students. Those factors refer to internal and external factors. For the internal factors including psychological state (lack of confidence, discourage, anxiety itself), linguistic knowledge (limited vocabulary, poor grammar, mispronunciation), and general knowledge (topics being discussed). And for the external factors containing performance situations (time, preparation, amount of support), and the learning atmosphere (classroom climate).

\section{References}

Bashir, M., Azeem, M., \& Dogar, A. H. (2016). Factor Effecting Students ' English Speaking Skills. British Journal of Arts and Social Sciences, 2(January 2011), 35-50.

Bashosh, S., Nejad, M. A., Rastegar, M., \& Marzban, A. (2013). The Relationship between Shyness, Foreign Language Classroom Anxiety, Willingness to Communicate, Gender, and EFL Proficiency. Theory and Practice in Language Studies, 3(11), 2098-2106. https://doi.org/10.4304/tpls.3.11.2098-2106

Brown, H. D. (2004). Language Assessment Principle and Classroom Practices. Pearson Education, Inc.

Chen, C. (2008). The relationship between foreign language anxiety and English achievement of Taiwan's junior high school students in school level 7 and 8. Tuanghai University, Taiwan.

Chen, Q. (2011). A Brief Analysis of Psychological Factors in SLA. Psychology Research, 02, 36-38. https://doi.org/10.5503/j.pr.2011.02.008

Creswell, J. W. (2012). Educational Research: Planning, Conducting, and Evaluating Quantitative and Qualitative Research (Fourth Edi). Pearson Education, Inc.

Doğan, A., \& Akbarov, A. (2014). Does anxiety really matters? Mediterranean Journal of Social Sciences, 5(9), 681-687. https://doi.org/10.5901/mjss.2014.v5n9p681

Education First. (2020). A Ranking of 100 Countries and Regions by English Skills. EF EPI EF English Proviency Index. 
Flick, U. (2007). Designing Qualitative Research. SAGE Publications Ltd.

Ganschow, L., \& Sparks, R. (1996). Anxiety about foreign language learning among high school women. Modern Language Journal, 80(2), 199-212. https://doi.org/10.1111/j.1540-4781.1996.tb01160.x

Gay, L. R., Mills, G. E., \& Airasian, P. (2012). Educational Research: Competencies for Analysis and Applications (Tenth Edit). Pearson Education, Inc.

Horwitz, E. (2001). Language Anxiety and Achievement. Annual Review of Applied Linguistics, 21, 112-126.

Horwitz, E. K., Horwitz, M. B., \& Cope, J. (1986). Foreign Language Classroom Anxiety. The Modern Language Journal, 70(2), 125-132. https://doi.org/10.1111/j.15404781.1986.tb05256.x

Mauludiyah, Y. (2014). the Correlation Between Students 'Anxiety and Their Ability in Speaking Class. http://repo.iain-tulungagung.ac.id/1267/1/The Correlation Between Students.pdf

Richard, J. C. (2008). Teaching Listening and Speaking: From Theory to Practice. 1-37.

Rustini. (2017). The Correlation between Foreign Language Anxiety and Speaking Achievement of the Eighth Grade Students of Madrasah Tsanawiyah Paradigma Palembang.

Sinaga, A. G. H., Syahrial, S., \& Hati, G. M. (2020). Students' Speaking Anxiety in English Class. Jadila: Journal of Development and Innovation in Language and Literature Education, 1(1), 44-56. https://doi.org/10.52690/jadila.v1i1.13

Tanveer, M. (2007). Investigation of the factors that cause language anxiety for ESL / EFL learners in learning speaking skills and the influence it casts on communication in the target language . By. June, 1-92. https://doi.org/10.13140/RG.2.1.1995.1129

Tuan, N. H., \& Mai, T. N. (2015). Factors Affecting Students' Speaking Performance at Le Thanh Hien High School. Asian Journal of Educaitonal Research, 3(2), 8-23.

Woodrow, L. (2006). Anxiety and speaking English as a second language. RELC Journal, 37(3), 308-328. https://doi.org/10.1177/0033688206071315 